\title{
Simultaneous estimation of in situ porosity and thermal structure from core sample measurements and resistivity log data at Nankai accretionary prism
}

\author{
Suguru Yabe ${ }^{1 *} \mathbb{D}$, Rina Fukuchi ${ }^{2}$, Yohei Hamada ${ }^{3}$ and Gaku Kimura ${ }^{4}$
}

\begin{abstract}
The shallow accretionary prism of the Nankai Trough is a location where both large interplate earthquakes and slow earthquakes occur. Since the physical properties of sedimentary materials are important topics for understanding the structure of the prism, numerous ocean drilling expeditions have been conducted in that region to obtain logging data and core samples. Although the physical properties of the obtained samples are normally measured onboard immediately after coring, estimations of in situ physical properties are difficult because of differences in laboratory and in situ physical conditions. Herein, we propose a new method for estimating in situ porosity from downhole electrical resistivity log data that evaluates in situ porosity and thermal structure simultaneously using correlations between the porosity and resistivity, and between the porosity and thermal conductivity that were established based on laboratory measurements. When constructing physical property correlations, X-ray computed tomography data play an important role in estimating the porosity of samples from which resistivity or thermal conductivity were measured. To validate our method, we compared the estimation with density log data collected at Site C0002 and found that the estimated in situ porosity shows good agreement with the in situ porosity converted from density log data. A comparison with porosity measured onboard for core and cutting samples showed that they are consistent with each other. With this new method, continuous distributions of in situ porosity and thermal structure can be estimated simultaneously based on resistivity log data and heat flow, which are basic quantities acquired during ocean drilling science expeditions.
\end{abstract}

Keywords: Accretionary prism, Subduction zones, Logging data, Electrical resistivity, In situ porosity, Thermal structure

\section{Introduction}

Ocean drilling science provides a way to reveal the structure and physical properties of accretionary prisms (e.g., Tobin and Kinoshita 2006). Two types of data, core samples and borehole geophysical logs, are usually acquired during ocean drilling. Because shallow accretionary prisms are composed of porous sedimentary materials,

\footnotetext{
*Correspondence: s.yabe@aist.go.jp

${ }^{1}$ Geological Survey of Japan, National Institute of Advanced Industrial Science and Technology (AIST), Tsukuba Central 7, 1-1-1 Higashi, Tsukuba, Ibaraki 305-8567, Japan

Full list of author information is available at the end of the article
}

their physical properties are mainly controlled by porosity (Archie 1942). Since those physical properties control seismogenesis on the plate boundary fault through various factors such as thermal structure (Hyndman et al. 1995; Moore and Saffer 2001), friction (Blanpied et al. 1991; Sawai et al. 2017), fluid distributions (van Keken et al. 2011; Kimura et al. 2012; Ji and Yoshioka 2017; Tanikawa et al. 2013; Hirono et al. 2016), and mechanical properties (Kitajima and Saffer 2012, 2014), estimating in situ porosity distributions is an important, although challenging, task. Although core samples and logging data acquired through ocean drilling can be used to estimate porosity, porosity values measured in onboard 
laboratories could be biased due to differences between the laboratory and in situ conditions (Hoffman and Tobin 2004). On the other hand, direct in situ measurement of porosity via density log and neutron porosity log data can provide more reliable information, but since these methods are not always available, electrical resistivity log data are usually converted to determine the in situ porosity based on empirical relationships.

For example, Conin et al. (2011) converted electrical resistivity log data to porosity using Archie's law (Archie 1942). However, since electrical resistivity also depends on temperature, it was necessary to assume the thermal structure and compensate for its effects. The parameters in Archie's law were estimated by fitting the porosity measured onboard the research vessel after correcting for the smectite dehydration effect. Sugihara et al. (2014) also estimated in situ porosity from the resistivity, which they further converted to thermal conductivity, in order to calculate the thermal structure using empirical correlations between them. However, as the thermal structure needs to be assumed in order to convert electrical resistivity to in situ porosity, a thermal structure that is different from the one finally estimated is normally assumed for this conversion.

These examples show that since the thermal structure and porosity structure were estimated separately in previous studies, the consistency between them should have been evaluated after their estimations; but this has not been done. This motivated us to develop a new method by which we could simultaneously estimate the thermal structure and in situ porosity. Accordingly, we herein propose an iterative estimation method for thermal structure and in situ porosity that uses resistivity log data, which automatically guarantees satisfactions of the empirical correlations between porosity, electrical resistivity, and thermal conductivity.

Data used in this study come from the Nankai Trough located off southwest Japan. The geological settings and data are explained in the next section, after which the proposed method is described in "Analysis" section. In "Physical property correlations from core samples" section, we begin our description by establishing roomtemperature conversion functions between porosity and electrical resistivity and between porosity and the thermal conductivity using the sample measurement data. Then, in the following section, we estimate the in situ porosity and thermal structure simultaneously so that the physical property correlations established in "Physical property correlations from core samples" section are satisfied. In "Discussion" section, we compare our estimations with the in situ measurements of porosity and temperature at the site to validate our proposed method. The geological interpretations of estimated in situ porosity are also discussed in "Discussion" section. Finally, we give the conclusions for this study.

\section{Geological setting and data}

As stated above, this study focused on the Nankai Trough located off southwest Japan, where the Nankai Trough Seismogenic Zone Experiment (NanTroSEIZE) (Tobin and Kinoshita 2006) project was conducted. At the Nankai Trough, the Philippine Sea Plate (PSP) is subducting beneath the continental plate (Miyazaki and Heki 2001) (Fig. 1). In this subduction zone, large interplate earthquakes have repeatedly caused ground shaking and related tsunamis that have resulted in devastating damage to human society (Ando 1975). In addition, recent geophysical observations have confirmed that slow earthquakes are also occurring at the shallowest part of the plate boundary fault (Asano et al. 2008; Nakano et al. 2016, 2018; Araki et al. 2017). The interesting features and shallow depth of the Nankai Trough motivated the start of the NanTroSEIZE project, which began in 2007, and multiple other expeditions have been conducted within the framework of the Integrated Ocean Drilling Program and the International Ocean Discovery Program (IODP) aboard the drilling vessel (D/V) "Chikyu".

Since then, the NanTroSEIZE project has obtained both logging data and core samples from drilled holes at various tectonic settings including the forearc (Kumano) basin (Sites C0002 and C0009), the trench slope (Sites C0001, C0004, C0008, C0010, C0018, C0021, and C0022), the prism toe (Sites C0006 and C0007), and incoming PSP (Sites C0011 and C0012). Of these, logging data obtained via the logging-while-drilling (LWD) technique enable measurements to be taken from holes soon after drilling, and are thus expected to decrease the invasive effects of mud or fluid that result from the drilling process. Basic LWD measurements include electrical resistivity, natural gamma rays, and compressional sonic wave velocity, although several additional measurements (such as density, neutron porosity, and the photoelectric factor) have been conducted for a few holes. The available logging data from these observations are summarized in Additional file 1: Table S1. Scientists on board the research vessels also analyze the sampled cores for their lithological, structural, and physical properties. These onboard physical property measurements include bulk density, porosity, thermal conductivity, electrical resistivity, compressional sonic wave velocity, natural gamma rays, magnetic susceptibility, and penetration strength, as well as X-ray computed tomography (XCT) measurements. The available physical properties' data measured by onboard scientists are summarized in Additional file 1: Table S2. 




Fig. 1 Regional map of the Nankai Trough. The circles show the site locations of NanTroSEIZE observations. The background color and contours show the bathymetry and topography in this region

We estimated the porosity and thermal structure below Site C0002 using electrical resistivity log data (Expedition 314 2009a; Strasser et al. 2014a; Tobin et al. 2015). This site was selected for three reasons. First, density log data, which can be compared with the porosity estimated with the proposed method, are also available for C0002. In situ temperature measurements are also available for C0002, which can be compared with our estimation. Second, C0002 is the deepest hole in the NanTroSEIZE project, and this site has been examined in previous studies, as discussed in "Comparison with other measurements and estimations" section. Third, at C0002, cuttings' samples are obtained in addition to core samples. The analysis and interpretation of cuttings' samples are difficult compared with those of core samples because cuttings' samples are mixed and aggregated with drilling mud, which influence the physical property measurement results. We compared the porosity measurements for cuttings' samples with our estimation to show the usefulness of cuttings' sample analysis. 


\section{Analysis}

Our method of estimating in situ porosity and thermal structure consists of two steps: estimating physical properties' correlations from core data and estimating in situ porosity and thermal structure simultaneously from logging data. Using the physical properties' measurements of core samples acquired in the shipboard laboratory at room temperature, we first establish conversion functions between porosity and electrical resistivity and between porosity and thermal conductivity. Then, we estimate the in situ porosity and thermal structure iteratively from resistivity $\log$ data so that the established physical property correlations are satisfied (Fig. 2).

\section{Physical property correlations from core samples}

In this section, we establish physical properties' correlations between porosity and electrical resistivity and between porosity and thermal conductivity using core sample data measured at room temperate in an onboard laboratory. Since core sample data from all sites (Expedition 315 2009a, b; Expedition 316 2009a, b, c, d; Expedition 319 2010; Expedition 322 2010a, b; Expedition 333 2012a, b, c; Strasser et al. 2014a, b, c; Tobin et al. 2015; Saffer et al. 2017) were used, we can estimate the average conversion functions in various environments of the Nankai Trough.

Difficulties in comparing porosity with electrical resistivity and thermal conductivity were resolved by analyzing XCT data. Since during the NanTroSEIZE expeditions, each physical property was usually measured using different parts of the core samples (e.g., Expedition 315 2009c; Expedition 316 2009e), we were unable to make direct comparisons between those physical properties. This problem was resolved by utilizing XCT data.

XCT imaging is a nondestructive analysis method that can be used to visualize the interior of sampled cores. Since all the cores sampled by D/V Chikyu (Expedition 315 2009c) were XCT scanned soon after their recovery, XCT data were available for almost the entire section of cores. The CT number, which is also known as

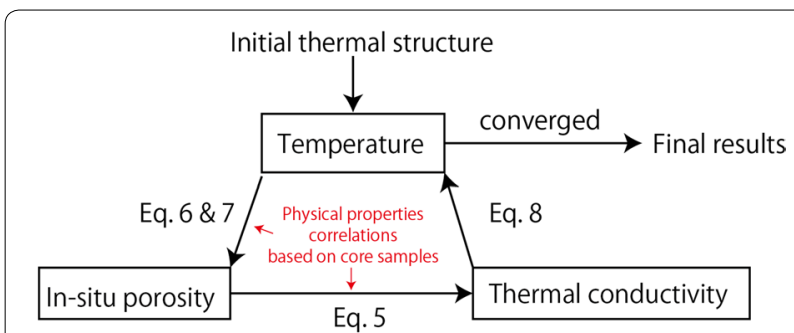

Fig. 2 Schematic diagram of iterative estimations for in situ porosity and thermal structure the linear attenuation coefficient, describes the strength of X-ray absorption by the scanned material, which is a function of its bulk density and chemical composition. As the sedimentary material everywhere in the Nankai Trough is basically composed of silicate minerals, such as clay minerals, quartz, and plagioclase, along with minor mixtures of calcite (e.g., Expedition 315 2009a, Screaton et al. 2009; Underwood et al. 2010), the CT number is expected to correlate well with the bulk density of the material. Therefore, the porosity of core samples, where the electrical resistivity or thermal conductivity is measured, can be estimated by analyzing XCT data.

\section{CT number vs. bulk density and porosity}

In the first step, we compare the bulk density and porosity of core samples measured by moisture and density (MAD) measurements with the CT number. In the MAD datasheet downloaded from the website (see Data availability), the top and bottom depths are specified for each sample (Fig. 3a). However, sometimes the same depth is written for both the top and bottom. In such cases, we assume that the bottom depth is $2 \mathrm{~cm}$ below the top depth. Because MAD measurements are used for the bulk density and porosity of the sample, the two values can be directly compared. Correlations between those values are fitted using a linear function. To exclude bad measurement data from the analysis, we do not use data with grain densities lower than $2.3 \mathrm{~g} / \mathrm{cm}^{3}$ or higher than $3.1 \mathrm{~g} / \mathrm{cm}^{3}$, which are too low or too high, respectively, for sedimentary materials in the Nankai Trough, which have previously been reported at about $2.7 \mathrm{~g} / \mathrm{cm}^{3}$ (e.g., Expedition 315 2009a; Tobin et al. 2015).

The MAD measurements for bulk density $\left(\rho\left[\mathrm{g} / \mathrm{cm}^{3}\right]\right)$ and porosity $(\phi)$ show good linear correlations (Fig. 4). The correlation can be written as.

$$
\rho=2.71-1.70 \times \phi,
$$

which yields a grain density of $2.71 \mathrm{~g} / \mathrm{cm}^{3}$ and a fluid density of $1.01 \mathrm{~g} / \mathrm{cm}^{3}$. The average grain density in the expedition reports was 2.6 to $2.7 \mathrm{~g} / \mathrm{cm}^{3}$ (Expedition 315 2009a, b; Expedition 316 2009a, b, c; Expedition 319 2010; Expedition 322 2010a; Expedition 333 2012c; Strasser et al. 2014a; Tobin et al. 2015), which is consistent with the value estimated here.

Next, we compare bulk density measurements with CT numbers. An XCT image slice is taken every $0.625 \mathrm{~mm}$ in the depth direction with each slice containing $512 \times 512$ pixels (Expedition 315 2009c). The CT numbers are calibrated such that air has a value of -1000 , water has a value of 0 , and the aluminum content has a value of 2467 to 2487 (Expedition 315 2009c; Gupta et al. 2018). An XCT image example is shown in Fig. 3b. Here, it can be seen that the interior of a sedimentary core is not 


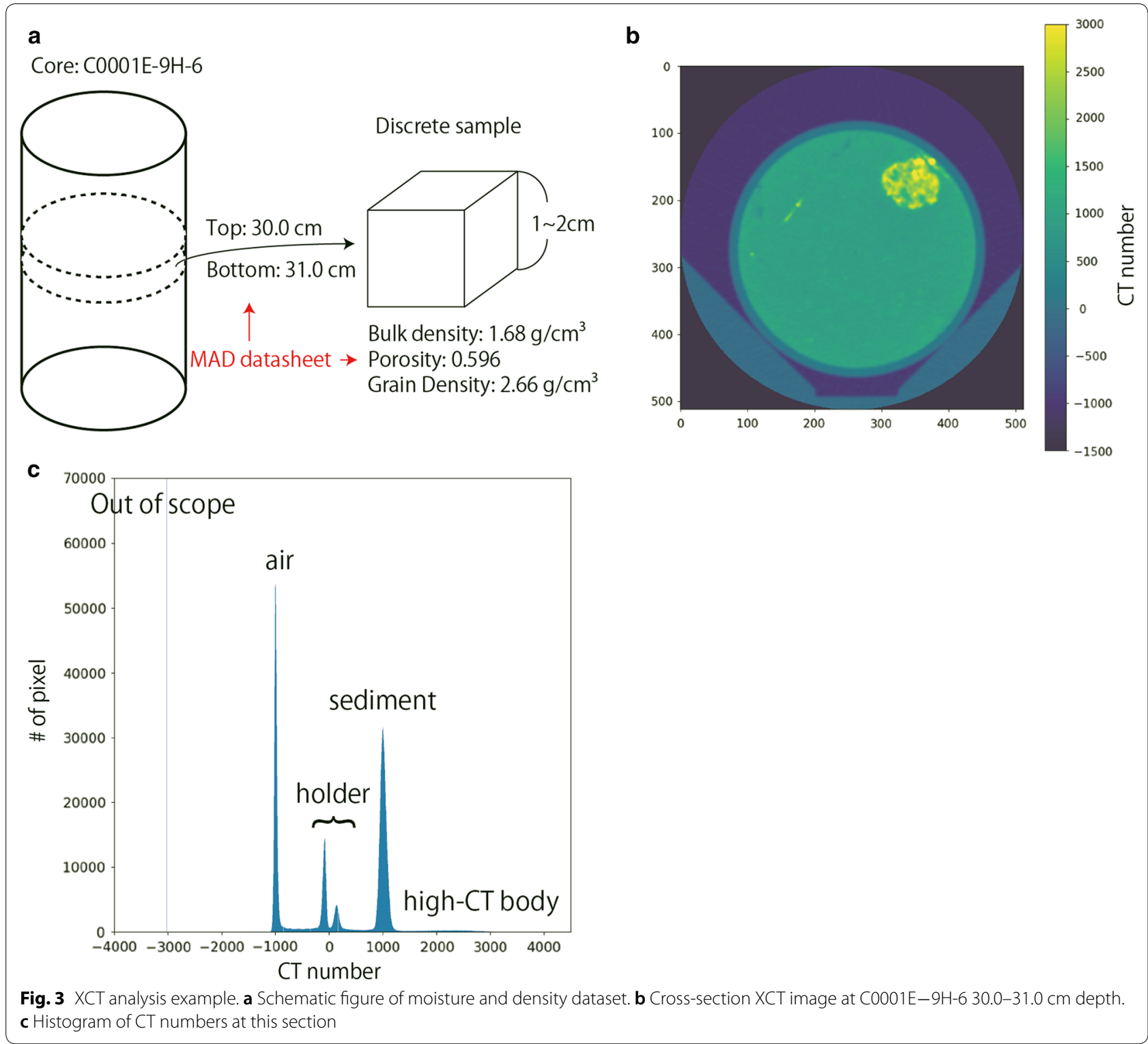

homogeneous, but it includes non-sedimentary components, such as pyrite with a high CT number. Alternatively, it can be fractured, which is expressed as a low CT number in the core holder. However, because onboard scientists are expected to take samples from homogeneous sedimentary lithology, anomalous CT numbers resulting from fractures or non-sedimentary components should not be included when comparing $\mathrm{CT}$ numbers with bulk density measured by MAD.

As discussed by Issanov et al. (2009), the thresholdselection method is problematic. Therefore, with their suggestion in mind, this study set the threshold adaptively for each MAD measurement to avoid such anomalous CT numbers. To accomplish this, we first picked CT numbers within the sections where the MAD samples are taken and converted them into histograms with a bin size of 3, as shown in Fig. 3c. In this figure, several peaks can be observed in the histogram. The highest peak at the left is an artificial value that represents the out-ofscope region at the four corners of the cross-sectional images. The two peaks around 0 correspond to the core holder, while the peak around 1000 shows sedimentary cores. The high-CT body seen in Fig. 3b has a small peak around the CT numbers of 2000 to 3000 . Accordingly, to define the average $\mathrm{CT}$ number in this section, we performed our calculations using data between the CT number 200 smaller and larger than the mode value of the highest peak above CT number 300 . We also referred 


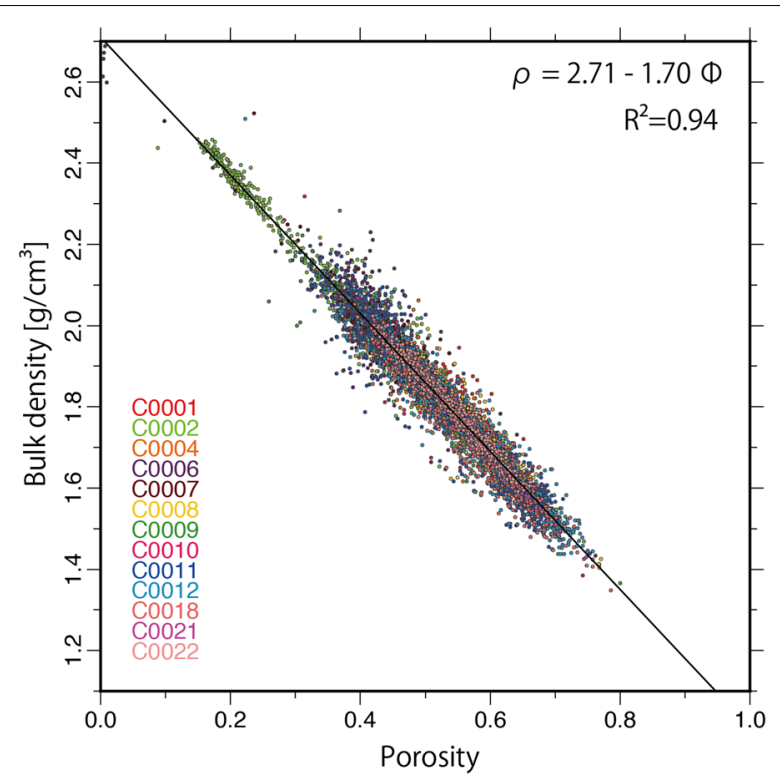

Fig. 4 Correlation between bulk density and porosity

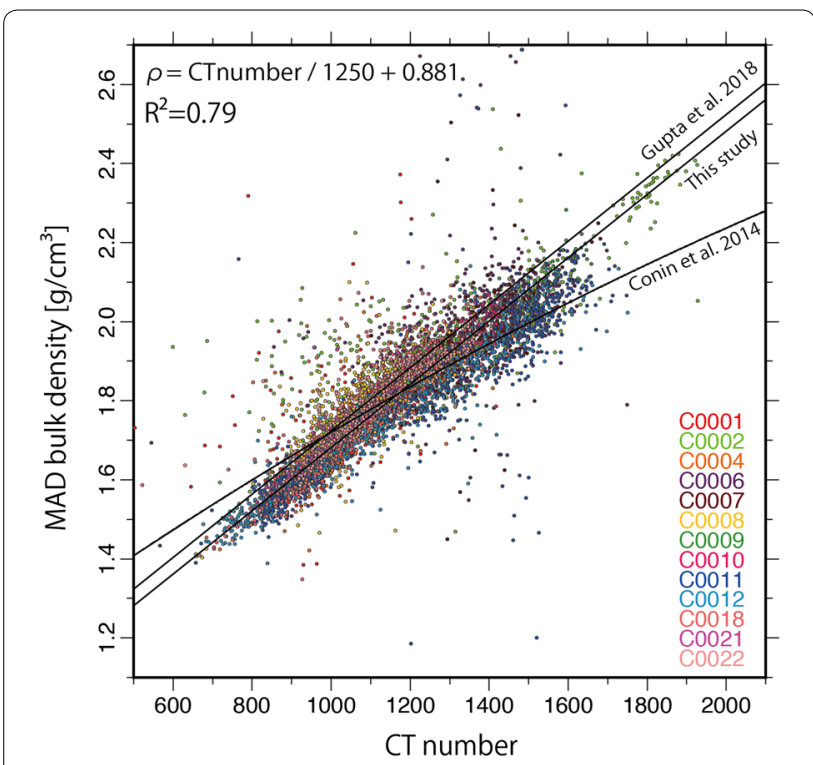

Fig. 5 Correlation between XCT values and bulk density

to the visual core descriptions produced by the onboard scientists and removed data from the sample analysis if it was for a non-sedimentary material (such as volcanic ash, tuff, basalt, or calcareous material).

The calculated average CT numbers were compared with the bulk density measured by MAD in Fig. 5 . The calibration of the XCT on D/V Chikyu suggests a correlation between the $\mathrm{CT}$ number and the bulk density (Gupta et al. 2018) as

$$
\rho=\text { CT number } / 1250+0.9237 \text {. }
$$

Equation 2 is basically consistent with the data, although the intercept is slightly shifted. Using the same slope as Eq. 2, because it is suggested by the calibration of the XCT on D/V Chikyu, the intercept was recalculated and the estimated equation for CT number correlation is

$$
\rho=\text { CT number } / 1250+0.88 \pm 0.08 \text {. }
$$

Although Eq. 3 agrees with Eq. 2 within the uncertainty, Eq. 3 better fits the data, especially with a low CT number $(<800)$ and a high CT number $(>1700)$. The coefficient of determination is also larger for Eq. $3\left(R^{2}=0.79\right)$ than for Eq. $2\left(R^{2}=0.73\right)$. Therefore, we use Eq. 3 in the following analysis.

Conin et al. (2014) estimated the correlation between the bulk density and XCT value by fitting using a quadratic function, which deviates from our data at higher $\mathrm{CT}$ values (Fig. 5). Because they did not show how the data fit the quadratic function in detail, it is difficult to discuss the reason for the differences. However, our careful choice of representative XCT values will exclude outlier data, which may have caused those differences (Iassonov et al. 2009).

\section{Porosity vs. electrical resistivity and thermal conductivity}

In the second step, we established the conversion functions between porosity and electrical resistivity and between porosity and thermal conductivity. Electrical resistivity and thermal conductivity in the datasheets are compared with porosity values calculated from the average $\mathrm{CT}$ number for measured samples using the same technique described in the previous section.

The electrical resistivity $(R)$ is fitted against porosity $(\phi)$ using Archie's law (Archie 1942) as

$$
\log \left(R\left(20^{\circ} C\right)\right)=\log \left(\operatorname{Rw}\left(20^{\circ} C\right)\right)+\log (a)-m \log (\phi),
$$

where $R_{w}$ is the electrical resistivity of the pore fluid in the laboratory $\left(20{ }^{\circ} \mathrm{C}\right)$, although deviations from the relationship could result because the effect of surface conduction caused by clay minerals contained in the sedimentary material decreases the electrical resistivity (e.g., Glover et al. 2000). The value of $R_{w}$ is assumed to be 0.208 (Shipley et al. 1995; Expedition 314 2009b). The value of $a$ is assumed to be 1 because the resistivity $R$ at $100 \%$ porosity should be the same as $R_{w}$. In this comparison, data from Holes C0011B, C0012A, and C0022B are excluded. The electrical resistivity measured for Holes C0011B and C0012A is much larger than the data measured from Holes C0011D (Expedition 333 2012a) and other sites with similar porosity. These differences may be 
due to inferior core quality or coring disturbances (Expedition 333 2012a). The datasheet for Hole C0022B shows that the electrical resistivity measured for the reference seawater is too high, which may have caused bias in the electrical resistivity of the samples (Strasser et al. 2014c). We also excluded one data point in C0006E-46X-1, which was a core with the value larger than $10 \Omega \mathrm{m}$, because the value was too high compared with neighboring sedimentary material samples. We fit the combined data for three orthogonal measurement axes (Expedition 315 2009c) using Eq. 4.

Figure 6 shows the correlations between the porosity estimated from XCT and the resistivity. The parameters in Eq. 4 are estimated by least-squares fitting assuming $R_{w}=0.208$ and $a=1$. The estimated parameter is $m=2.52 \pm 0.75$. The value of $m$ normally used is $m \sim 2$ (Conin et al. 2011; Strasser et al. 2014a; Tobin et al. 2015), which is consistent with the estimated value within the uncertainty of 1 sigma. However, since the uncertainty is relatively large, the choice of this parameter will be a source of error when estimating in situ porosity from the resistivity $\log$ in "In situ porosity and thermal structure estimation from resistivity log data" section.

The thermal conductivity $k$ is fitted against porosity $\phi$ with the geometrical mean model (Brigaud and Vasseur 1989; Harris et al. 2011; Sugihara et al. 2014) as

$$
\log (k)=\phi \log \left(k_{f}\right)+(1-\phi) \log \left(k_{s}\right),
$$

where $k_{f}$ and $k_{s}$ are the thermal conductivity of the pore fluid and grains, respectively. The thermal conductivity

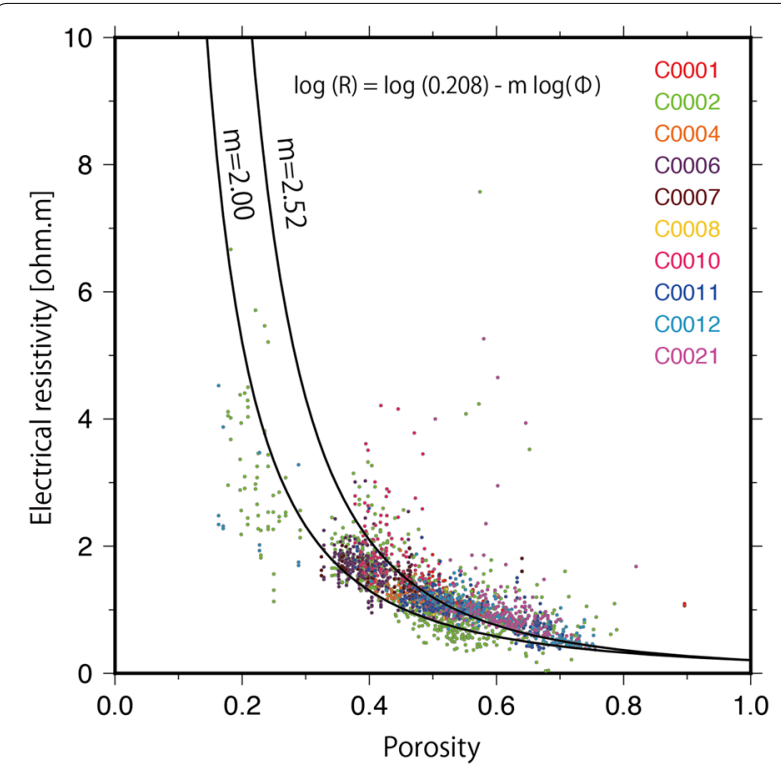

Fig. 6 Correlation between XCT-derived porosity and electrical resistivity of seawater $k_{f}$ is $0.6 \mathrm{~W} / \mathrm{mK}$ (Harris et al. 2011; Sugihara et al. 2014). Figure 7 shows the correlation between the porosity estimated from XCT and the thermal conductivity. The thermal conductivity for grain $\left(k_{s}\right)$ is estimated to be 2.29 with lower and upper 1-sigma uncertainty values of 1.84 and 2.84, respectively. Sugihara et al. (2014) estimated the grain thermal conductivity for Hole C0002A and showed that its value at the shallow part, defined as 0 to $600 \mathrm{~m}$ below the seafloor (mbsf), ranges between 1.0 and $3.0 \mathrm{~W} / \mathrm{mK}$, whereas the value is between 2.0 and 4.0 at the deep part (600-1200 mbsf). Since we use the wider dataset initially, the grain thermal conductivity estimated in this study has the average value. Expedition reports also reported a grain thermal conductivity of $\sim 2-3 \mathrm{~W} /$ mK (Expedition 322 2010a, Expedition 322 2010b; Tobin et al. 2015).

\section{In situ porosity and thermal structure estimation from resistivity log data Method}

In this section, the in situ porosity and thermal structure are estimated by converting the resistivity log data (Fig. 2). In situ porosity can be converted from the resistivity log because Archie's law is applicable between porosity and electrical resistivity. However, the thermal structure is needed as a priori information to convert the resistivity log because the fluid resistivity depends on the temperature $T$, and the resistivity log value was measured under in situ thermal conditions. Therefore, Archie's law can be written as



Fig. 7 Correlation between XCT-derived porosity and thermal conductivity 


$$
\log (R(T))=\log (R w(T))+\log (a)-m \log (\phi) .
$$

The temperature dependence of the fluid resistivity is assumed (Shipley et al. 1995; Expedition 314 2009b) as

$$
R_{w}(T)=R_{w}\left(20^{\circ} \mathrm{C}\right) \times \frac{48}{28+T}
$$

In order to avoid bad quality data due to borehole invasion, only resistivity logs from deep depths of the investigation were used for our analyses. Specifically, deep button resistivity was used for Hole C0002A (Expedition 314 2009a) and C0002F (Strasser et al. 2014a), and R39 Phase resistivity was used for C0002N and C0002P (Tobin et al. 2015). A moving average with a 20-m-depth band was applied to those data before they were used in the analyses.

On the other hand, the thermal structure can be estimated if we know the in situ porosity structure as a priori information. As we established via the conversion function in the previous section, in situ porosity is related to the thermal conductivity. Therefore, the thermal structure can be calculated with the observed heat flow $Q$ (Bullard 1939) as

$$
T\left(z_{i}\right)=T_{s f}+\sum \alpha\left(z_{i}\right) \frac{Q}{k_{i}} \Delta z_{i},
$$

where $z$ is depth and we assume the temperature at the seafloor $T_{s f}$ is $2{ }^{\circ} \mathrm{C}$. The temperature dependence of the thermal conductivity for porous sediments is corrected following Harris et al. (2011) so that it increases by $1 \%$ with every $20^{\circ} \mathrm{C}$ increase of temperature. $\alpha(z)$ in Eq. (8) is the correction factor for rapid sedimentation.

The heat flow observed at the seafloor at this site is 40 $\mathrm{mW} / \mathrm{m}^{2}$ (Expedition 315 2009b). Heat flow estimated using a bottom-simulating reflector (BSR) is also $40-50$ $\mathrm{mW} / \mathrm{m}^{2}$ (Ohde et al. 2018). However, the heat flow observed at the seafloor could be suppressed if the sedimentation rate is so high that the thermal structure is not in a steady state (Harris et al. 2011). At C0002, the uplift caused by splay fault activity since $\sim 2 \mathrm{Ma}$ has resulted in rapid sedimentation in the Kumano Basin (Strasser et al. 2009; Expedition 315 2009b). According to Harris et al. (2011), the heat flow corrected for the bathymetry effect is $44 \mathrm{~mW} / \mathrm{m}^{2}$, although when corrected for further sedimentation, the heat flow is $57 \mathrm{~mW} / \mathrm{m}^{2}$. Sugihara et al. (2014) estimated the heat flow at $\sim 800 \mathrm{~m}$ depth based on the in situ temperature measurement settled in DONET, which also yields $57 \mathrm{~mW} / \mathrm{m}^{2}$. Based on these observations, we used a heat flow of $57 \mathrm{~mW} / \mathrm{m}^{2}$. In addition, $\alpha(z)$ is 0.78 at the seafloor and increases linearly to 1.0 at 840 mbsf, where the boundary between Units 2 and 3 is identified and the sedimentation rate decreases (Expedition 315 2009b).

At C0002, methane hydrate has been detected as BSR in a seismic reflection study (Kinoshita et al. 2011; Ohde et al. 2018). The existence of this hydrate is also suggested by resistive peaks in logging data, which was classified as Zone A of Log Unit II 218-400 m depth (Expedition 314 2009a). As the physical properties' correlations established in Physical property correlations from core samples section do not include hydrate, the estimated conversion functions of Eqs. 5 and 6 cannot be applied to the hydrate zone. Therefore, based on the core sample measurements, a constant thermal conductivity of $1.3 \mathrm{~W} /$ $\mathrm{mK}$ is assumed at this depth (Expedition 315 2009b). The in situ porosity calculated in the hydrate zone with Eq. 6 should be an underestimation because hydrate usually shows higher electrical resistivity than sedimentary material.

We obtain the final estimation of in situ porosity and thermal structure by conducting iterative estimations of those structures (Fig. 2). In specific, we tested two initial thermal structures with constant thermal gradients of 37.4 and $20.0 \mathrm{mK} / \mathrm{m}$. The former is a good initial assumption based on the analysis of in situ temperature measurements taken in C0002 shallower than 900 mbsf by Sugihara et al. (2014). The latter is an example of a bad initial assumption that was included for reference purposes. The iteration is stopped when the root mean square of the difference in temperature structure falls below $10^{-4}$. The obtained structures satisfy physical property correlations among porosity, electrical resistivity and thermal conductivity (Eqs. 5 and 6), which resolves the problems encountered with previous methods. We conducted estimations with four parameter sets to evaluate the uncertainty of our estimation due to scattered data in physical property correlations. As for the grain thermal conductivity $k_{s}$, we tested the upper bound value of $2.84 \mathrm{~W} / \mathrm{mK}$ as well as the estimated value of $2.29 \mathrm{~W} / \mathrm{mK}$ because the majority of the grain thermal conductivities estimated by previous studies are around 2-3 W/mK (Expedition 322 2010a, b; Sugihara et al. 2014; Tobin et al. 2015). As for the exponent $m$ in Eq. 6 , the estimated value of 2.52 and the value normally used of 2.00 are tested.

\section{Results}

Figure 8 shows the estimated thermal structure and in situ porosity for $k_{s}=2.29$ and $m=2.52$ with two different (good and bad) initial thermal structure assumptions. With a good initial assumption, the initially assumed thermal structure and the thermal structure calculated in the first iterative step show differences of less than $10{ }^{\circ} \mathrm{C}$, which suggests that consistency exists between 


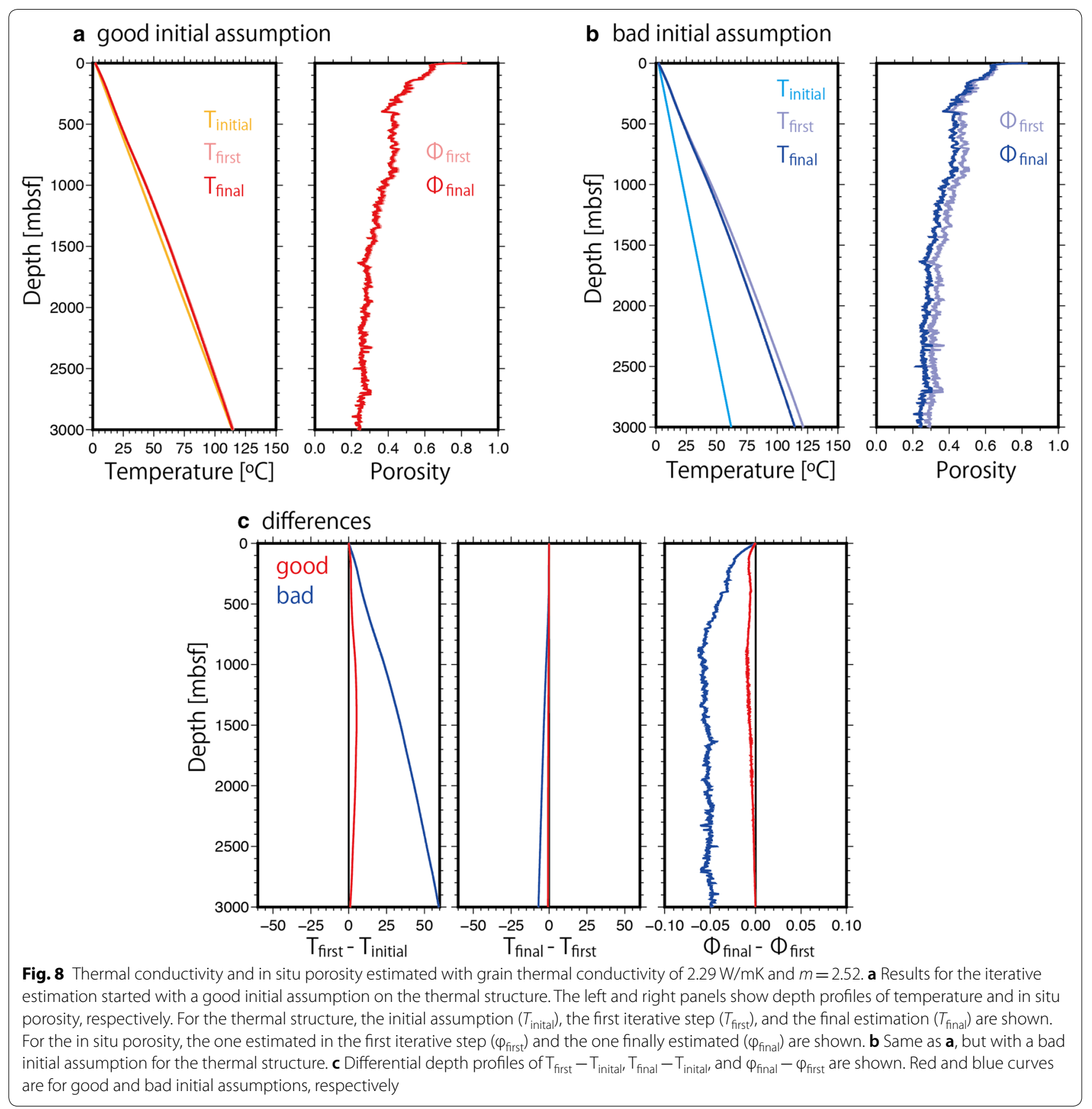

the assumed thermal structure and the calculated in situ porosity (Fig. 8a, c). On the other hand, with a bad initial assumption, the initially assumed thermal structure and the thermal structure calculated in the first iterative step show differences of larger than $50^{\circ} \mathrm{C}$, which means that inconsistencies exist between the assumed thermal structure and the calculated in situ porosity (Fig. 8b, c).
With a good initial thermal structure, the in situ porosity estimated from the initial thermal structure shows only a few percentage points of difference from the finally estimated porosity (Fig. 8a, c). However, with a bad initial thermal structure, the in situ porosity estimated from the initial thermal structure and the finally estimated in situ porosity show differences of $\sim 6 \%$ (Fig. 8b, c). This highlights the importance of obtaining good thermal structure estimations before conducting 
porosity estimations when using existing methods, which can be accomplished more easily using our new iterative method. The estimations resulting from use of our new iterative method with good and bad initial thermal structures converge to the same values.

Figure 9 shows that the estimated in situ porosity is not significantly affected by the assumed grain thermal

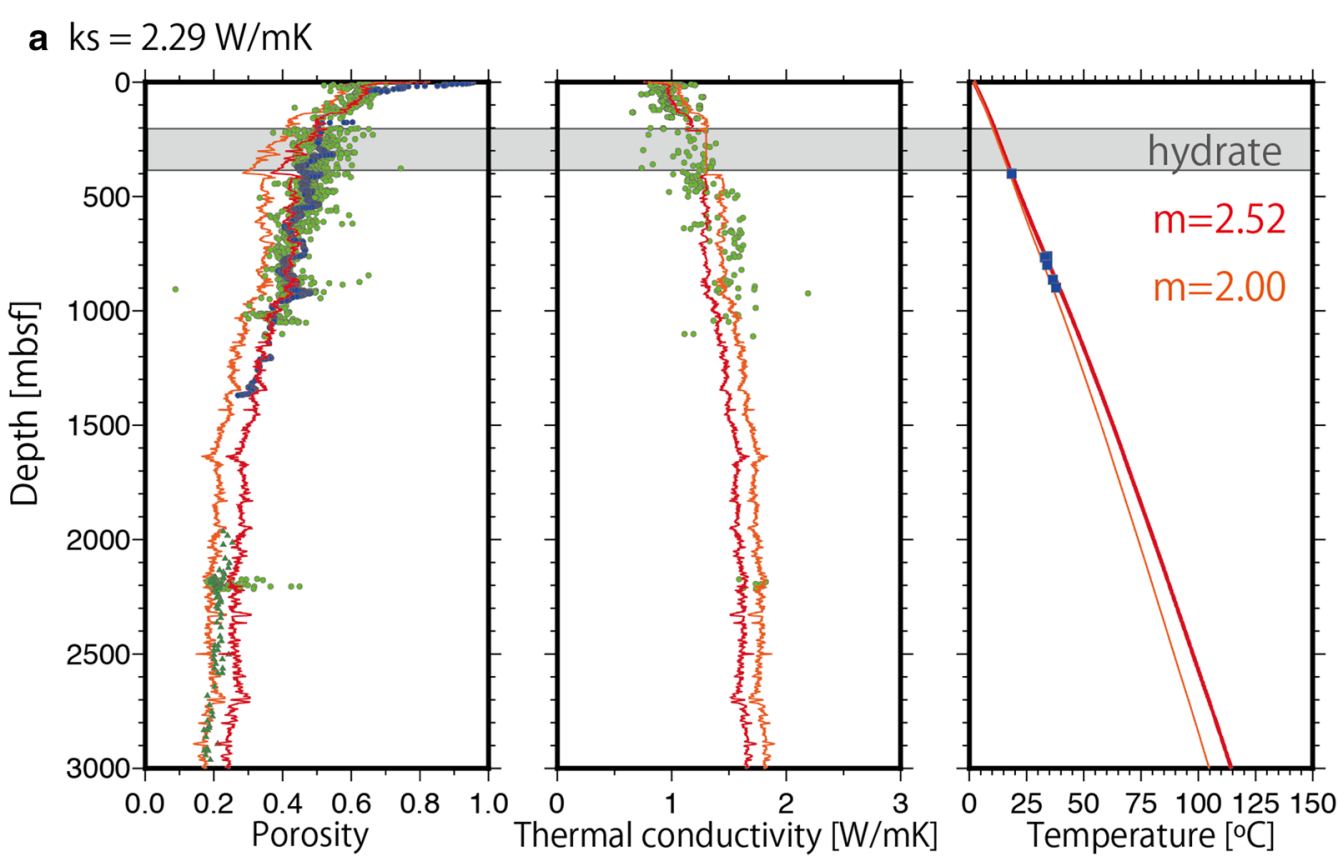

b $\mathrm{ks}=2.84 \mathrm{~W} / \mathrm{mK}$



Fig. 9 Depth distributions for estimated in situ porosity, thermal conductivity, and temperature at Site C0002. a Grain thermal conductivity at $2.29 \mathrm{~W} / \mathrm{mK}$. b Grain thermal conductivity at $2.84 \mathrm{~W} / \mathrm{mK}$. The red and orange lines are values estimated with $m=2.52$ and 2.00 , respectively. The blue circles are in situ porosity values calculated from density log data. The green circles are core porosity values measured onboard. The dark green triangles are the porosity values for cuttings measured onboard. Blue squares are in situ temperature measurements. Gray bands at 200-400 mbsf depth represent the hydrate zone 
conductivity, although it is affected by parameter $m$. The estimation with $m=2.52$ results in $\sim 0.1$ higher porosity than with $m=2.00$. With $m=2.52$, the estimated in situ porosity decreases rapidly with depth from close to 1.0 at the seafloor to around $0.5-0.6$ at $~ 135$ mbsf. The estimated values are not reliable between 200 and 400 mbsf because the hydrate causes higher resistivity, thereby resulting in an apparently lower porosity. Below $400 \mathrm{mbsf}$, the estimated in situ porosity gently decreases from $\sim 0.45$ at $400 \mathrm{mbsf}$ to $\sim 0.40$ at $940 \mathrm{mbsf}$. At that point, the estimated in situ porosity decreases more steeply to 0.28 at $1660 \mathrm{msbf}$. The deep accretionary prism is divided into three blocks with constant porosity: 16601970 mbsf at $\sim 0.29,1970-2710 \mathrm{mbsf}$ at $\sim 0.26$, and 2710 mbsf-at $\sim 0.24$.

The estimated thermal conductivity is affected by both the grain thermal conductivity and the parameter $m$. An estimation conducted with $m=2.52$ resulted in a lower thermal conductivity than an estimation conducted with $m=2.00$. Larger grain thermal conductivity values resulted in larger thermal conductivity. The estimated thermal conductivity increased with the in situ porosity from $0.6 \mathrm{~W} / \mathrm{mK}$ at the seafloor to $1.7 \mathrm{~W} / \mathrm{mK}$ at 3000 mbsf with $m=2.52$ and a grain thermal conductivity of $2.29 \mathrm{~W} / \mathrm{mK}$.

Much as the thermal conductivity varies with the assumed grain thermal conductivity and parameter $m$, the calculated temperature also varies. For a constant value of $m$, a lower grain thermal conductivity level results in higher temperatures. For $m=2.52$ and $k_{s}=2.29 \mathrm{~W} / \mathrm{mK}$, the temperature increases almost linearly from $2{ }^{\circ} \mathrm{C}$ at the seafloor to $115^{\circ} \mathrm{C}$ at $3000 \mathrm{mbsf}$.

\section{Discussion}

\section{Comparison with other measurements and estimations}

To validate our new method of simultaneously estimating in situ porosity, thermal conductivity, and thermal structure from the resistivity log values, we compared our estimations with measurements and estimations produced by other studies. In Hole C0002A, a density log was acquired (Expedition 314 2009a) that can be compared with the in situ porosity estimated from the resistivity $\log$ data. We convert the density log measurements to porosity using the conversion function in Eq. 1, and then compare the results with the estimated values. Since the density log data are affected by the borehole diameter, we refer to the caliper log and remove data when the caliper size is larger than $9.5 \mathrm{in}$. Next, the moving average with the 20-m-depth band is applied to compare it with the calculated in situ porosity. The estimated in situ porosity with $m=2.52$ is consistent below $\sim 400 \mathrm{~m}$ depth with the porosity converted from the density log data. The estimated in situ porosity reproduces not only the overall trend of the porosity converted from the density log data but also the fine-scale fluctuations of the porosity structure. For example, porosity values converted from the density log have high peaks at 700-800 mbsf, around 900 mbsf, and around 1200 mbsf. Such features can be seen in the estimated in situ porosity as well. At the depth range of 200-400 mbsf, the estimated in situ porosity is underestimated compared with the core sample data and the porosity converted from the density log data due to the existence of the hydrate (Miyakawa et al. 2014). At the very shallow portion of the well, the porosity converted from density $\log$ data value is very high (close to 1.0), which is consistent with the estimated in situ porosity.

The core sample porosity measured by MAD falls around the estimation with $m=2.52$, except for the very shallow portion, in spite of different temperature and pressure conditions. This consistency between the in situ and onboard measured porosity is expected as Hoffman and Tobin (2004) observed only 2\% differences between the onboard porosity measurements and the porosity converted from the density log at sites 1173 , 1174, and 808. As suggested by anelastic strain recovery analysis conducted on the core samples (Lin et al. 2007; Byrne et al. 2009), the rebound of drilled cores may take a significant amount of time. This could be why the MAD measured porosity level would nearly reflect the in situ value. At the shallowest portion of the well, MAD measurements show a porosity level of about 0.65 , which is smaller than the estimated in situ porosity level and the porosity level converted from the density log data. A similar situation was observed at Site 1173 of Ocean Drilling Program (Shipboard Scientific Party 2002) where shipboard scientists reported that it is due to low-quality logging data, even though such quality problems had not been observed for the shallowest part of C0002. In the interval of 1300 and 3000 mbsf, cuttings' samples were mainly collected instead of cores. Strasser et al. (2014a) and Tobin et al. (2015) considered that intact cuttings, which remain after hard washing of cuttings' samples, represent the in situ formation properties, even though the depth accuracy of cuttings' samples is low. Figure 9 shows that the porosity level of MAD for intact cuttings is consistent with the in situ porosity level estimated from the resistivity log data. This coincidence supports the usefulness of analyzing intact cuttings.

The onboard thermal conductivity measurement results are roughly consistent with the estimated values, including those for deep depths around 2200 mbsf. Onboard measurements are limited and scattered, and it is difficult to use such a sparse dataset for thermal structure calculations. Our method can estimate the continuous distribution of thermal conductivity, which enables thermal structure estimation. Kinoshita et al. (2011) estimated the 
Table 1 The residuals between the estimated in situ porosity and the porosity estimated from the density log

\begin{tabular}{llll}
\hline & & $\boldsymbol{m}$ & \\
\cline { 3 - 4 } & & $\mathbf{2 . 0 0}$ & $\mathbf{2 . 5 2}$ \\
\hline$k_{\mathrm{s}}$ & $\mathbf{2 . 2 9}$ & 0.12 & 0.06 \\
& $\mathbf{2 . 8 4}$ & 0.11 & 0.06 \\
\hline
\end{tabular}

Table 2 The residuals between the estimated thermal structure and the in situ temperature measurements

\begin{tabular}{llll}
\hline & & $m$ & \\
\cline { 3 - 4 } & & $\mathbf{2 . 0 0}$ & $\mathbf{2 . 5 2}$ \\
\hline$k_{\mathrm{s}}$ & $\mathbf{2 . 2 9}$ & 1.81 & 0.94 \\
& $\mathbf{2 . 8 4}$ & 4.23 & 1.84 \\
\hline
\end{tabular}

temperature at 400 mbsf where BSR is observed in seismic reflection surveys as about $19{ }^{\circ} \mathrm{C}$ by considering the stability of the hydrate. Sugihara et al. (2014) estimated the in situ temperature at 700-900 mbsf using thermistors deployed during IODP Expedition 332 of NanTroSEIZE (Expedition 332 2011; Kimura et al. 2013). Their estimation is $\sim 33{ }^{\circ} \mathrm{C}$ at $\sim 760 \mathrm{mbsf}$ and $\sim 38{ }^{\circ} \mathrm{C}$ at $\sim 900$ mbsf. Those in situ measurements are consistent with our thermal structure estimation.

Sugihara et al. (2014) estimated the thermal structure beneath Site C0002 down to the plate boundary fault using thermal conductivity data down to $\sim 1200 \mathrm{mbsf}$ and resistivity log data down to $\sim 2000$ mbsf. According to their calculations, the temperature at $3000 \mathrm{mbsf}$ is 92 and $100{ }^{\circ} \mathrm{C}$, assuming grain thermal conductivity levels of 2.5 and $3.0 \mathrm{~W} / \mathrm{mK}$, respectively. Their estimation is slightly lower than our estimation of $105-115{ }^{\circ} \mathrm{C}$ with $m=2.52$ because our thermal conductivity level is lower than the estimation by Sugihara et al. (2014), in which, assuming the grain thermal conductivity of $2.5 \mathrm{~W} / \mathrm{mK}$, the thermal conductivity increases from $1.5 \mathrm{~W} / \mathrm{mK}$ at $1000 \mathrm{mbsf}$ to $2.1 \mathrm{~W} / \mathrm{mK}$ at $3000 \mathrm{mbsf}$. However, in our estimation, the thermal conductivity increases from 1.4 to $1.6 \mathrm{~W} / \mathrm{mK}$ at $1000 \mathrm{mbsf}$ to $1.6-1.8 \mathrm{~W} / \mathrm{mK}$ at $1600 \mathrm{mbsf}$ with grain thermal conductivity levels of 2.29 and $2.84 \mathrm{~W} / \mathrm{mK}$, and become constant below 1600 mbsf.

We next calculated the residuals between our estimations and in situ measurements (i.e., the porosity estimated from the density $\log$ and in situ temperature measurements) to evaluate the accuracy of our estimations. Data in the hydrate zone were excluded from these calculations. The residuals between the estimated in situ porosity and the porosity estimated from the density log (Table 1 ) shows that $m=2.52$ is more appropriate than $m=2.00$, whereas the effect of grain thermal conductivity is small. On the other hand, the residuals between the estimated thermal structure and in situ temperature measurements (Table 2) show that $\left(k_{s}, m\right)=(2.29,2.52)$ is more appropriate than the other parameter sets. From those results, we conclude that of the four sets considered in this study, $\left(k_{s}, m\right)=(2.29,2.52)$ is the best parameter set for use when estimating in situ porosity and thermal structure in the Nankai Trough.

\section{Geological interpretations}

From the seafloor to $940 \mathrm{mbsf}$, the estimated in situ porosity shows an exponentially decreasing trend with depth in regions where compaction due to gravity and/ or regional stress occurs (e.g., Athy 1930; Bahr et al. 2001). Based on the lithological and logging descriptions, $921.73 \mathrm{mbsf}$ and $935.6 \mathrm{mbsf}$ are defined as the base of the forearc basin (Kumano Basin), respectively (Expedition 314 2009a; Expedition 315 2009b). The stress state within the Kumano Basin is estimated to be extensional due to gravity based on the existence of normal faults (Expedition 314 2009a) and borehole breakouts (Lin et al. 2010; Chang et al. 2010). Below 940 mbsf, the estimated in situ porosity shows a linear decrease, the rate of which is higher than for the shallower portion. The lithological and logging descriptions suggest that an older accretionary wedge exists beneath the Kumano Basin (Expedition 314 2009a; Expedition 315 2009b). Although the current stress state of this old accretionary wedge is extensional to strike-slip, the wedge has a complex stress history and should have been severely deformed by the compressional stress state caused by the subduction, as has been observed at other sites in the prism toe and trench slope (Chang et al. 2010). Such sedimentary material, which has experienced a complex stress history, would no longer show a simple exponential decrease of porosity with depth.

Below $1660 \mathrm{mbsf}$, the estimated in situ porosity does not decrease with depth, but is constant within each block; $29(\sim 21) \%$ in 1660-1970 mbsf, $26(\sim 19) \%$ in 1970-2710 mbsf, and $\sim 24(\sim 17) \%$ in $2710-3000$ mbsf with a grain thermal conductivity of $2.29 \mathrm{~W} / \mathrm{mK}$ and $m=2.52$ (2.00). Based on observations of cuttings' samples, the depth of $\sim 1660 \mathrm{mbsf}$, where the decreasing trend of the estimated in situ porosity changes, also corresponds to the boundary of the lithological units (Tobin et al. 2015). The disappearance of the decreasing trend in the estimated in situ porosity with depth may suggest that the principle driving force for sedimentary material compaction changes from vertical to horizontal stress due to strong tectonic compression. Chang et al. (2010) estimated stress magnitudes from borehole breakout analyses and rock mechanics and showed that 
the horizontal stress becomes larger than the vertical stress at 1000-1400 mbsf. Meanwhile, Kitajima et al. (2017) estimated stress magnitudes from the empirical relationship between P-wave velocity and porosity levels and found that the horizontal stress gets larger than vertical stress at 1000-1400 mbsf. Hamada et al. (2018) estimated the strength of rock using drilling parameters and found strength increases at around $2800 \mathrm{mbsf}$, which may also correspond to the depth where the estimated in situ porosity shows a stepwise decrease. Note that as the temperature reaches $100{ }^{\circ} \mathrm{C}$ at around $2600 \mathrm{mbsf}$, the transition from smectite to illite in the sedimentary material completes (Underwood 2018), which may affect the strength of rock and porosity level distributions. Stepwise decreases in porosity can be observed in cuttings' samples as well. Those observations show that the complex stress history of the accretionary prism prevents us from approximating the porosity decrease with depth using a simple exponential function.

\section{Conclusions}

Analyzing the physical properties of sedimentary materials is important for understanding the structure of shallow accretionary prisms and the slip behavior of plate boundary faults. Hence, the NanTroSEIZE project has conducted several IODP expeditions aimed at obtaining core and cuttings' samples as well as logging data in the Nankai Trough off southwest Japan. Generally speaking, the physical properties of core samples and cuttings are measured soon after collection, but differences in temperature and pressure conditions between laboratory and in situ environments make it difficult to estimate the in situ physical properties accurately.

Accordingly, this study developed a method of estimating the in situ porosity and thermal structure simultaneously using resistivity log data and correlations between the physical properties (porosity, electrical resistivity, and thermal conductivity) derived from onboard sample measurements. This method enables us to estimate continuous distributions of in situ porosity, thermal conductivity, and thermal structure data from information routinely acquired during IODP expeditions. In addition, we use unique XCT data collected by the D/V Chikyu, which is dedicated to NanTroSEIZE project, to establish accurate physical property correlations for the onboard measurements.

We applied our new method to Site C0002, where partial density log data are also available, and found that our in situ porosity estimates obtained from resistivity log values show good agreement with the in situ porosity estimated from the density log data. The porosity measured from core and intact cuttings' samples also shows good agreement, which suggests that MAD porosity also closely reflects in situ properties. Since the calculated thermal structure is also consistent with in situ measurements, these results support the validity of our new method.

\section{Supplementary information}

Supplementary information accompanies this paper at https://doi. org/10.1186/s40623-019-1097-4.

Additional file 1. Summary tables of available LWD data and core samples data in NanTroSEIZE.

\section{Acknowledgements}

This study was made possible by participating in the IODP workshop "CoreLog-Seismic Integration at Sea" on D/V Chikyu. S. Y. would like to extend deep appreciation to JAMSTEC/CDEX (especially Dr. Toczko, Dr. Maeda, Dr. Sanada, and Dr. Kido), and to the laboratory technicians of Marine Works Japan, Ltd. (especially Mr. Kurasawa for advice on the treatment of XCT data) for the assistance provided to onboard participants during the cruise. Special appreciation is also extended to Mantle Quest Japan, Ltd. for operating DN Chikyu.

\section{Authors' contributions}

All authors contributed to research planning. SY analyzed the XCT and physical properties' data and constructed numerical code to estimate porosity and thermal structure. All authors interpreted the results. All authors read and approved the final manuscript.

\section{Funding}

This research was supported by the management expense of Japan Agency for Marine-Earth Science and Technology (JAMSTEC) and the National Institute of Advanced Industrial Science and Technology (AIST).

\section{Data availability}

All logging and sample data used in this study are available at http://sio7. jamstec.go.jp.

\section{Competing interests}

The authors declare that they have no competing interests.

\section{Author details}

${ }^{1}$ Geological Survey of Japan, National Institute of Advanced Industrial Science and Technology (AIST), Tsukuba Central 7, 1-1-1 Higashi, Tsukuba, Ibaraki 305-8567, Japan. ${ }^{2}$ Geoengineering Headquarters, Dia Consultants Co., Ltd., 2-272-3 Yoshino-cho, Kita-ku, Saitama, Saitama 331-0811, Japan. ${ }^{3}$ Institute for Extra-cutting-edge Science and Technology Avant-garde Research, Kochi Institute for Core Sample Research, Japan Agency for Marine-Earth Science and Technology, 200 Monobe Otsu, Nankoku-shi, Kochi 783-8502, Japan. ${ }^{4}$ Department of Marine Environment and Resources, Tokyo University of Marine Science and Technology, No. 2 Building 311, 4-5-7 Konan, Minato-ku, Tokyo 108-8477, Japan.

Received: 4 June 2019 Accepted: 23 October 2019 Published online: 07 November 2019

\section{References}

Ando M (1975) Source mechanisms and tectonic significance of historical earthquakes along the Nankai Trough, Japan. Tectonophysics 27:1 19-140. https://doi.org/10.1016/0040-1951(75)90102-X

Araki E, Saffer DM, Kopf AJ, Wallace LM, Kimura T, Machida Y et al (2017) Recurring and triggered slow-slip events near the trench at the Nankai trough subduction megathrust. Science 356(6343):1157. https://doi.org/10.1126/ science.aan3120

Archie GE (1942) The electrical resistivity log as an aid in determining some reservoir characteristics, JPT. J Pet Technol 5:1-8

Asano Y, Obara K, Ito Y (2008) Spatiotemporal distribution of very-low frequency earthquakes in Tokachi-oki near the junction of the Kuril and 
Japan trenches revealed by using array signal processing. Earth Planets Space 60(8):871-875. https://doi.org/10.1186/BF03352839

Athy LF (1930) Density, porosity, and compaction of sedimentary rocks. Am Assoc Petrol Geol Bull J Internat 110:577-590

Bahr DB, Hutton EWH, Syvitski JPM, Prason LF (2001) Exponential approximations to compacted sediment porosity profiles. Comp Geosci 27:691-700

Blanpied ML, Lockner DA, Byedee JD (1991) Fault stability inferred from granite sliding experiments at hydrothermal conditions. Geophys Res Lett 18(4):609-612. https://doi.org/10.1029/91GL00469

Brigaud F, Vasseur G (1989) Mineralogy, porosity and fluid control on thermal conductivity of sedimentary rocks. Geophys J 98:525-542

Bullard EC (1939) Heat flow in South Africa. Proc R Soc London, Ser A 173:474-502

Byrne TB, Lin W, Tsutsumi A, Yamamoto Y, Lewis JC, Kanagawa K, Kitamura Y, Yamaguchi A, Kimura G (2009) Anelastic strain recovery reveals extension across SW Japan subduction zone. Geophys Res Lett 36:L23310. https:// doi.org/10.1029/2009GL040749

Chang C, McNeill LC, Moore JC, Lin W, Conin M, Yamada Y (2010) In situ stress state in the Nankai accretionary wedge estimated from borehole wall failures. Geochem Geophys Geosyst 11:Q0AD04. https://doi. org/10.1029/2010gc003261

Conin M, Bourlange S, Henry P, Boiselet A, Gaillot P (2014) Distribution of resistive and conductive structures in Nankai accretionary wedge reveals contrasting stress paths. Tectonophysics 611:181-191. https://doi. org/10.1016/j.tecto.2013.11.025

Conin M, Henry P, Bourlange S, Raimbourg H, Reuschlé T (2011) Interpretation of porosity and LWD resistivity from the Nankai accretionary wedge in light of clay physicochemical properties: evidence for erosion and local overpressuring. Geochem Geophys Geosyst 12:07. https://doi. org/10.1029/2010gc003381

Expedition 314 Scientists (2009a) Expedition 314 Site C0002. In: Kinoshita M, Tobin H, Ashi J, Kimura G, Lallement S, Screaton EJ, Curewitz D, Masago H, Moe KT, and the Expedition 314/315/316 Scientists, Proc. IODP, 314/315/316: Washington, DC (Integrated Ocean Drilling Program Management International, Inc.). https://doi.org/10.2204/iodp.proc.31431 5316.114 .2009

Expedition 314 Scientists (2009b) Expedition 314 methods. In: Kinoshita M, Tobin H, Ashi J, Kimura G, Lallement S, Screaton EJ, Curewitz D, Masago H, Moe KT, and the Expedition 314/315/316 Scientists, Proc IODP, 314/315/316: Washington, DC (Integrated Ocean Drilling Program Management International, Inc.). https://doi.org/10.2204/iodp.proc.31431 5316.112 .2009

Expedition 315 Scientists (2009a) Expedition 315 Site C0001. In: Kinoshita M, Tobin H, Ashi J, Kimura G, Lallemant S, Screaton EJ, Curewitz D, Masago H, Moe KT, and the Expedition 314/315/316 Scientists, Proc. IODP, 314/315/316: Washington, DC (Integrated Ocean Drilling Program Management International, Inc.). https://doi.org/10.2204/iodp.proc.314315316.123.2009

Expedition 315 Scientists (2009b) Expedition 315 Site C0002. In: Kinoshita M, Tobin H, Ashi J, Kimura G, Lallemant S, Screaton EJ, Curewitz D, Masago $H$, Moe KT, and the Expedition 314/315/316 Scientists, Proc. IODP, 314/315/316: Washington, DC (Integrated Ocean Drilling Program Management International, Inc.). https://doi.org/10.2204/iodp.proc.31431 5316.124 .2009

Expedition 315 Scientists (2009c) Expedition 315 methods. In: Kinoshita M, Tobin H, Ashi J, Kimura G, Lallemant S, Screaton EJ, Curewitz D, Masago H, Moe KT, and the Expedition 314/315/316 Scientists, Proc. IODP, 314/315/316: Washington, DC (Integrated Ocean Drilling Program Management International, Inc.). https://doi.org/10.2204/iodp.proc.31431 5316.122.2009

Expedition 316 Scientists (2009a) Expedition 316 Site C0006. In: Kinoshita M, Tobin H, Ashi J, Kimura G, Lallemant S, Screaton EJ, Curewitz D, Masago H, Moe KT, and the Expedition 314/315/316 Scientists, Proc IODP, 314/315/316: Washington, DC (Integrated Ocean Drilling Program Management International, Inc.). https://doi.org/10.2204/iodp.proc.31431 5316.134.2009

Expedition 316 Scientists (2009b) Expedition 316 Site C0007. In: Kinoshita M, Tobin H, Ashi J, Kimura G, Lallemant S, Screaton EJ, Curewitz D, Masago $\mathrm{H}$, Moe KT, and the Expedition 314/315/316 Scientists, Proc. IODP, 314/315/316: Washington, DC (Integrated Ocean Drilling Program Management International, Inc.). https://doi.org/10.2204/iodp.proc.31431 5316.135 .2009
Expedition 316 Scientists (2009c) Expedition 316 Site C0004. In: Kinoshita M, Tobin H, Ashi J, Kimura G, Lallemant S, Screaton EJ, Curewitz D, Masago H, Moe KT, and the Expedition 314/315/316 Scientists, Proc. IODP, 314/315/316: Washington, DC (Integrated Ocean Drilling Program Management International, Inc.). https://doi.org/10.2204/iodp.proc.314315316.133.2009

Expedition 316 Scientists (2009d) Expedition 316 Site C0008. In: Kinoshita M, Tobin H, Ashi J, Kimura G, Lallemant S, Screaton EJ, Curewitz D, Masago $H$, Moe KT, and the Expedition 314/315/316 Scientists, Proc. IODP, 314/315/316: Washington, DC (Integrated Ocean Drilling Program Management International, Inc.). https://doi.org/10.2204/iodp.proc.31431 5316.136.2009

Expedition 316 Scientists (2009e) Expedition 316 methods. In: Kinoshita M, Tobin H, Ashi J, Kimura G, Lallemant S, Screaton EJ, Curewitz D, Masago H, Moe KT, and the Expedition 314/315/316 Scientists, Proc. IODP, 314/315/316: Washington, DC (Integrated Ocean Drilling Program Management International, Inc.). https://doi.org/10.2204/iodp.proc.31431 5316.132.2009

Expedition 319 Scientists (2010) Site C0009. In Saffer D, McNeill L, Byrne T, Araki E, Toczko S, Eguchi N, Takahashi K, and the Expedition 319 Scientists, Proc. IODP, 319: Tokyo (Integrated Ocean Drilling Program Management International, Inc.). https://doi.org/10.2204/iodp.proc.319.103.2010

Expedition 322 Scientists (2010a) Site C0011. In: Saito S, Underwood MB, Kubo Y, and the Expedition 322 Scientists, Proc. IODP, 322: Tokyo (Integrated Ocean Drilling Program Management International, Inc.). https://doi. org/10.2204/iodp.proc.322.103.2010

Expedition 322 Scientists (2010b) Site C0012. In Saito S, Underwood MB, Kubo Y, and the Expedition 322 Scientists, Proc. IODP, 322: Tokyo (Integrated Ocean Drilling Program Management International, Inc.). https://doi. org/10.2204/iodp.proc.322.104.2010

Expedition 332 Scientists (2011) Methods. In: Kopf A, Araki E, Toczko S (eds) Expedition 332 Scientists, Proc. IODP, 332: Tokyo (Integrated Ocean Drilling Program Management International, Inc.). https://doi.org/10.2204/ iodp. proc.332.102.2011

Expedition 333 Scientists (2012a) Site C0011. In Henry P, Kanamatsu T, Moe K, and the Expedition 333 Scientists, Proc. IODP, 333: Tokyo (Integrated Ocean Drilling Program Management International, Inc.). https://doi. org/10.2204/iodp.proc.333.104.2012

Expedition 333 Scientists (2012b) Site C0012. In Henry P, Kanamatsu T, Moe K, and the Expedition 333 Scientists, Proc. IODP, 333: Tokyo (Integrated Ocean Drilling Program Management International, Inc.). https://doi. org/10.2204/iodp.proc.333.105.2012

Expedition 333 Scientists (2012c) Site C0018. In Henry P, Kanamatsu T, Moe K, and the Expedition 333 Scientists, Proc. IODP, 333: Tokyo (Integrated Ocean Drilling Program Management International, Inc.). https://doi. org/10.2204/iodp.proc.333.103.2012

Glover PWJ, Hole MJ, Pous J (2000) A modified Archie's law for two-conducting phases. Earth Planet Sci Lett 180:369-383. https://doi.org/10.1016/S0012 $-821 \times(00) 00168-0$

Gupta L, Tanikawa W, Hamada Y, Hirose T, Ahagon N, Sugihara T, Abe N, Nomura S, Masaki Y, Wu H, Lin W, Kinoshita M, Yamada Y (2018) Examination of gas hydrate-bearing deep ocean sediments by X-ray Computed Tomography and verification of physical property measurements of sediments. Marine Petrol Geol. https://doi.org/10.1016/j.marpe tgeo.2018.05.033 (in press)

Hamada Y, Kitamura M, Yamada Y, Sanada Y, Sugihara T, Saito S, Moe K, Hirose T (2018) Continuous depth profile of the rock strength in the Nankai accretionary prism based on drilling performance parameters. Sci Rep 8:2622. https://doi.org/10.1038/s41598-018-20870-8

Harris RN, Schmidt-Schierhorn F, Spinelli G (2011) Heat flow along the NanTrOSEIZE transect: results from IODP expeditions 315 and 316 offshore the Kii Peninsula, Japan. Geochem Geophys Geosyst 12:16. https://doi. org/10.1029/2011 gc003593

Hirono T, Tsuda K, Tanikawa W, Ampuero JP, Shibazaki B, Kinoshita M, Mori J (2016) Near-trench slip potential of megaquakes evaluated from fault properties and conditions. Sci Rep 6:28184. https://doi.org/10.1038/srep28184

Hoffman, N. W., and Tobin, H.J. (2004) An empirical relationship between velocity and porosity for underthrust sediments in the Nankai Trough accretionary prism, in Mikada, $H_{\text {., }}$ et al., Proceedings of the Ocean Drilling Program, Scientific results, Volume 190/196: College Station, Texas, Ocean Drilling Program: http://www-odp.tamu.edu/publications/19019 6SR/355/355.htm 
Hyndman RD, Wang K, Yamano M (1995) Thermal constraints on the seismogenic portion of the southwestern Japan subduction thrust. J Geophys Res 100(15):15373-15392. https://doi.org/10.1029/2011JB008840

lassonov P, Gebrenegus T, Tuller M (2009) Segmentation of X-ray computed tomo-graphy images of porous materials: a crucial step for characterization and quantitative analysis of pore structures. Water Resour Res 45:W09415. https://doi.org/10.1029/2009WR008087

Ji Y, Yoshioka S (2017) Slab dehydration and earthquake distribution beneath southwestern and central Japan based on three-dimensional thermal modeling. Geophys Res Lett. https://doi.org/10.1002/2016GL072295

van Keken PE, Hacker BR, Syracuse EM, Abers GA (2011) Subduction factory: 4. Depth-dependent flux of $\mathrm{H}_{2} \mathrm{O}$ from subducting slabs worldwide. J Geophys Res 116:1401. https://doi.org/10.1029/2010jb007922

Kimura T, Araki E, Takayama H, Kitada K, Kinoshita M, Namba Y, Kyo M (2013) Development and performance tests of a sensor suite for a long-term borehole monitoring system in seafloor settings in the Nankai Trough. Japan IEEE J Ocean Engineer 38(2):383-395. https://doi.org/10.1109/ JOE.2012.2225293

Kimura G, Hina S, Hamada Y, Kameda J, Tsuji T, Kinoshita M, Yamaguchi A (2012) Runaway slip to the trench due to rupture of highly pressurized megathrust beneath the middle trench slope: the tsunamigenesis of the 2011 Tohoku earthquake off the east coast of northern Japan. Earth Planet Sci Lett 339-340:32-45. https://doi.org/10.1016/j.epsl.2012.04.002

Kinoshita M, Moore GF, Kido YN (2011) Heat flow estimated from BSR and IODP borehole data: Implication of recent uplift and erosion of the imbricate thrust zone in the Nankai Trough off Kumano. Geochem Geophys Geosyst. 12:Q0AD18. https://doi.org/10.1029/2011 gc003609

Kitajima H, Saffer DM (2012) Elevated pore pressure and anomalously low stress in regions of low frequency earthquakes along the Nankai Trough subduction megathrust. Geophys Res Lett 39:L23301. https://doi. org/10.1029/2012GL053793

Kitajima H, Saffer DM (2014) Consolidation state of incoming sediments to the Nankai Trough subduction zone: implications for sediment deformation and properties. Geochem Geophys Geosyst. https://doi. org/10.1002/2014GC005360

Kitajima H, Saffer D, Sone H, Tobin H, Hirose T (2017) In situ stress and pore pressure in the deep interior of the Nankai accretionary prism, integrated Ocean Drilling Program Site C0002. Geophys Res Lett 44:9644-9652. https://doi.org/10.1002/2017GL075127

Lin W et al (2010) Present-day principal horizontal stress orientations in the Kumano forearc basin of the southwest Japan subduction zone determined from IODP NanTroSEIZE drilling Site C0009. Geophys Res Lett 37:L13303. https://doi.org/10.1029/2010GL043158

Lin W, Yeh E, Ito H, Hirono T, Soh W, Wang C, Ma K, Hung J, Song S (2007) Preliminary results of stress measurements using drill cores of TCDP Hole-A an application of anelastic strain recovery method to three-dimensional in situ stress determination. Terr Atmos Oceanic Sci 18:379-393

Miyakawa A, Saito S, Yamada Y, Tomaru H, Kinoshita M, Tsuji T (2014) Gas hydrate saturation in Kumano Basin. Island Arc 23:142-156. https://doi. org/10.1111/iar.12064

Miyazaki S, Heki K (2001) Crustal velocity field of southwest Japan: subduction and arc-arc collision. J Geophys Res 106(B3):4305-4326. https://doi. org/10.1029/2000JB900312

Moore JC, Saffer D (2001) Updip limit of the seismogenic zone beneath the accretionary prism of southwest Japan: an effect of diagenetic to low-grade metamorphic process and increasing effective stress. Geology 29:183-186. https://doi.org/10.1130/0091-7613(2001)029\%3c0183:ULOTSZ\%3e2.0.CO;2

Nakano M, Hori T, Araki E, Kodaira S, Ide S (2018) Shallow very-low-frequency earthquakes accompany slow slip events, Nankai trough, Japan. Nat Commun 9:984. https://doi.org/10.1038/s41467-018-03431-5

Nakano M, Hori T, Araki E, Takahashi N, Kodaira S (2016) Ocean floor networks capture low-frequency earthquake event. EOS. https://doi. org/10.1029/2016EO052877

Ohde A, Otsuka H, Kioka A, Ashi J (2018) Distribution and depth of bottomsimulating reflectors in the Nankai subduction margin. Earth Planets Space 70:60. https://doi.org/10.1186/s40623-018-0833-5

Saffer D, Kopf A, Toczko S, Araki E, Carr S, Kimura T, Kinoshita C, Kobayashi R, Machida Y, Rösner A, and Wallace LM (2017) Site C0010. With contributions by S. Chiyonobu, K. Kanagawa, T. Kanamatsu, G. Kimura, and M.B. Underwood. In: Saffer D, Kopf A, Toczko S, and the Expedition 365 Scientists, NanTroSEIZE Stage 3: Shallow Megasplay Long-Term Borehole
Monitoring System. Proceedings of the International Ocean Discovery Program, 365: College Station, TX (International Ocean Discovery Program). https://doi.org/10.14379/iodp.proc.365.103.2017

Sawai M, Niemeijer AR, Hirose T, Spiers CJ (2017) Frictional properties of JFAST core samples and implications for slow earthquakes at the Tohoku subduction zone. Geophys Res Lett 44:8822-8831. https://doi. org/10.1002/2017GL073460

Screaton EJ, Kimura G, Curewitz D, and the Expedition 316 Scientists (2009) Expedition 316 summary. In: Kinoshita M, Tobin H, Ashi J, Kimura G, Lallemant S, Screaton EJ, Curewitz D, Masago H, Moe KT, and the Expedition 314/315/316 Scientists, Proc. IODP, 314/315/316: Washington, DC (Integrated Ocean Drilling Program Management International, Inc.). https:// doi.org/10.2204/iodp.proc.314315316.131.2009

Shipboard Scientific Party (2002) Site 1173, In H. Mikada, K. Becker, J.C. Moore, A. Klaus, et al. (Eds.), Proc. ODP, Initial Rep., vol. 196 (2002), pp. 1-97, [CD-ROM]. Available from: Ocean Drilling Program, Texas A\&M University, College Station TX 77845-9547, USA

Shipley TH, Ogawa Y, Blum P, et al (1995) Proc. ODP, Init. Repts., 156: College Station, TX (Ocean Drilling Program). https://doi.org/10.2973/odp.proc. ir.156.1995

Strasser M, Moore GF, Kimura G, Kitamura Y, Kopf AJ, Lallemant S, Park J, Screaton EJ, Su X, Underwood MB, Zhao X (2009) Origin and evolution of a splay fault in the Nankai accretionary wedge. Nat Geosci 2:648-652. https ://doi.org/10.1038/NGEO609

Strasser M, Dugan B, Kanagawa K, Moore GF, Toczko S, Maeda L, Kido Y, Moe KT, Sanada Y, Esteban L, Fabbri O, et al. (2014a) Site C0002. In: Strasser M, Dugan B, Kanagawa K, Moore GF, Toczko S, Maeda L, and the Expedition 338 Scientists, Proc. IODP, 338: Yokohama (Integrated Ocean Drilling Program). https://doi.org/10.2204/iodp.proc.338.103.2014

Strasser M, Dugan B, Kanagawa K, Moore GF, Toczko S, Maeda L, Kido Y, Moe KT, Sanada Y, Esteban L, Fabbri O, et al. (2014b) Site C0021. In: Strasser M, Dugan B, Kanagawa K, Moore GF, Toczko S, Maeda L, and the Expedition 338 Scientists, Proc. IODP, 338: Yokohama (Integrated Ocean Drilling Program). https://doi.org/10.2204/iodp.proc.338.106.2014

Strasser M, Dugan B, Kanagawa K, Moore GF, Toczko S, Maeda L, Kido Y, Moe KT, Sanada Y, Esteban L, Fabbri O, et al. (2014c) Site C0022. In: Strasser M, Dugan B, Kanagawa K, Moore GF, Toczko S, Maeda L, and the Expedition 338 Scientists, Proc. IODP, 338: Yokohama (Integrated Ocean Drilling Program). https://doi.org/10.2204/iodp.proc.338.107.2014

Sugihara T, Kinoshita M, Araki E, Kimura T, Kyo M, Namba Y, Kido Y, Sanada Y, Thu M (2014) Re-evaluation of temperature at the updip limit of locked portion of Nankai megasplay inferred from IODP Site C0002 temperature observatory. Earth Planets Space 66:107. https://doi. org/10.1186/1880-5981-66-107

Tanikawa W, Hirose T, Mukoyoshi H, Tadai O, Lin W (2013) Fluid transport properties in sediments and their role in large slip near the surface of the plate boundary fault in the Japan Trench. Earth Planet Sci Lett 382:150-160. https://doi.org/10.1016/j.epsl.2013.08.052

Tobin HJ, Kinoshita M (2006) NanTroSEIZE: the IODP Nankai Trough seismogenic zone experiment. Sci Drill 2:23-27. https://doi.org/10.2204/iodp. sd.2.06.2006

Tobin H, Hirose T, Saffer D, Toczko S, Maeda L, Kubo Y, Boston B, Broderick A, Brown K, Crespo-Blanc A, Even E, et al. (2015) Site C0002. In: Tobin H, Hirose T, Saffer D, Toczko S, Maeda L, Kubo Y, and the Expedition 348 Scientists, Proc. IODP, 348: College Station, TX (Integrated Ocean Drilling Program). https://doi.org/10.2204/iodp.proc.348.103.2015

Underwood MB (2018) The origin of strata within the inner accretionary prism of Nankai Trough: evidence from clay mineral assemblages along the NanTroSEIZE transect. Island Arc 27:e12252. https://doi.org/10.1111/ iar.12252

Underwood MB, Saito S, Kubo Y, and the Expedition 322 Scientists (2010) Expedition 322 summary. In: Saito S, Underwood MB, Kubo Y, and the Expedition 322 Scientists, Proc. IODP, 322: Tokyo (Integrated Ocean Drilling Program Management International, Inc.). https://doi.org/10.2204/ iodp.proc.322.101.2010

\section{Publisher's Note}

Springer Nature remains neutral with regard to jurisdictional claims in published maps and institutional affiliations. 